\title{
SISTEM PERHITUNGAN PPH PASAL 21 ATAS PEMBAYARAN GAJI PEGAWAI KANTOR PADA PT. PERKEBUNAN NUSANTARA III SEI MANGKEI KABUPATEN SIMALUNGUN
}

\author{
Yulica Wardany ${ }^{1}$, Dedi Suhendro ${ }^{2}$, Fani Ad'ha Purba ${ }^{3}$ \\ AMIK Tunas Bangsa Pematangsiantar \\ Jl. Jend. Sudirman Blok A No. 1,2,3, 21117 \\ yulica0823@gmail.com ${ }^{1}$
}

\begin{abstract}
Abstrak
Abstrak - Pajak Penghasilan Pasal 21 adalah Pajak yang dikenakan terhadap penghasilan orang pribadi dalam negeri berupa gaji, tunjangan dan pembayaran lainnya. Tujuan penelitihan ini yakni untuk mengetahui pelaksanaan perhitungan, pemotongan, penyetoran dan pelaporan Pajak Penghasilan Pasal 21 pegawai pada PT. Perkebunan Nusantara III Sei Mangkei Kab. Simalungun. Objek penelitihan Tugas Akhir ini adalah "Sistem Perhitungan PPH Pasal 21 Atas Pembayaran Gaji Pegawai Kantor pada PT. Perkebunan Nusantara III Sei Mangkei Kab. Simalungun". Berdasarkan Pasal 21 Ayat 1 Undang-Undang Nomor 36 Tahun 2008 tentang Pajak Penghasilan, Pohak yang wajib melakukan pemotongan Pajak Penghasilan Pasal 21 adalah pemberi kerja, dalam hal ini PT. Perkebunan Nusantara III Sei Mangkei Kaab. Simalungun, selain memotong Pajak Penghasilan Pasal 21, Pemotong menyetorkan Pajak Penghasilan Pasal 21 tersebut ke Kantor Pos dengan menggunakan SSP (Surat Setor Pajak), hasil dari penyetoran tersebut kemudian harus dilaporkan ke kantor pelayanan pajak (KPP) Simalungun, dimana perusahaan tersebut terdaftar.
\end{abstract}

Kata Kunci : MySQL, Microsoft Visual Studio 2010, Pajak Penghasilan Pasal 21 


\section{Pendahuluan}

Pajak merupakan sumber penerimaan Negara yang digunakan untuk membiayai kepentingan umum yang akhirnya juga mencakup kepentingan pribadi individu seperti kepentingan rakyat, pendidikan, kesejahteraan rakyat, kemakmuran rakyat dan sebagainya. Sehingga pajak merupakan salah satu alat untuk mencapai tujuan Negara. Perpajakan merupakan salah satu perwujudan dari pengabdian dan peran serta warga negara sebagai wajib pajak, untuk secara langsung dan bersama-sama melaksanakan kewajiban perpajakan yang akandigunakan untuk membiayai segala keperluan negara dan pembangunan nasional [1].

Akuntansi Perpajakan merupakan salah satu dimensi Akuntansi yang menyediakan informasi yang berhubungan dengan Aspek Perpajakan, tetang bisnis dan transaksi keuangan kepada mereka yang ingin mengelola bisnis dan transaksi keuangan dan aspek perpajakan dari suatu entitas Akuntansi [2] pemungutan pajak yang dilakukan oleh penerimaan Negara. Lagipula penerimaan Negara dari pajak dapat dijadikan indicator atas peran serta masyarakat (sebagai subjek pajak) dalam kontribusinya melakukan kewajiban perpajakan, karena pembayaran pajak yang dilakukan akan dikembalikan lagi kepada masyarakat dalam bentuk tidak langsung. PPh Pasal 21 merupakan pajak atas penghasilan berupa gaji, upah, honor, tunjangan dan pembayaran lain dengan nama dan dalam bentuk apapun sehubungan dengan pekerjaan atau jabatan, jasa, dan kegiatan yang dilakukan oleh wajib pajak orang pribadi dalam negeri.

\section{Tinjauan Pustaka}

A. Pengertian Teori

Aplikasi adalah suatu subkelas dari suatu perangkat lunak komputer yang memanfaatkan kemampuan komputer secara langsung untuk melakukan suatu tugas yang diinginkan pengguna. Aplikasi dapat juga dikatakan sebagai penerjemah perintah-perintah yang dijalankan pengguna komputer untuk 
diteruskan ke atau diproses oleh perangkat keras. Aplikasi merupakan program yang secara langsung dapat melakukan proses-proses yang digunakan dalam komputer oleh pengguna. Aplikasi merupakan kumpulan dari file-file tertentu yang berisi kode program yang menghubungkan antara pengguna dan perangkat keras Komputer.

Aplikasi sering juga disebut sebagai perangkat lunak, merupakan program komputer yang isi instruksinya dapat diubah dengan mudah. Aplikasi pada umumnya digunakan untuk mengontrol perangkat keras (yang sering disebut sebagai device driver), melakukan proses perhitungan, dan berinteraksi dengan aplikasi yang lebih mendasar lainnya (seperti sistem operasi, dan bahasa pemrograman). Secara umum aplikasi dapat dibagi menjadi 3 tingkatan yaitu tingkatan program aplikasi (application program misalnya Microsoft Office), tingkatan sistem operasi (operating system misalnya Microsoft Windows), dan tingkatan bahasa pemrograman (misalnya PHP).

\section{B. Perancangan}

Perancangan merupakan langkah awal yang dilakukan dalam membangun sebuah aplikasi. Perancangan adalah suatu tahap yang dilakukan untuk menentukan bagaimana suatu sistem menyelesaikan permasalahan yang ada, dengan mengatur komponen-komponen dalam sistem tersebut sehingga sistem dapat bekerja sebagaimana yang diharapkan

\section{PPH Pasal 21}

Pajak Penghasilan Pasal 21 merupakan pajak penghasilan yang dikenakan atas penghasilan berupa gaji, upah, honorium, tunjangan, dan pembayaran lain dengan nama apapun sehubungan dengan pekerjaan, jasa atau kegiatan yang dilakukan oleh Wajib Pajak orang pribadi dalam negeri. Pegawai atau orang pribadi yang memperoleh penghasilan lain selain penghasilan yang pajaknya telah dibayar dan dipotong bersifat final, pada akhir tahun pajak diwajibkan untuk menyampaikan SPT Tahunan PPh dan atas Pajak Penghasilan Pasal 21 yang telah dipotong oleh pemberi kerja dapat dijadikan sebagai kreditpajak atas Pajak Penghasilan yang terutang pada akhir tahun [3]. 
Sistem Perhitungan PPH Pasal 21 atas Pembayaran Gaji Pegawai Kantor pada PT. Perkebunan Nusantara III Sei Mangkei

Perusahaan yang PPh badannya tidak dikenal bersifat final, diupayakan seminimal mungkin memberikan kesejahteraan karyawan dalam bentuk natura atau kenikmatan (benefit in kids), karena pengeluaran tersebut tidak dapat dibebankan sebagai biaya perusahaan. Sebagai gantinya untuk kesejahteraan pegawai diberikan dalam bentuk tunjangan, sehingga bisa dibiayakan (mengurangi profit). Adapun tunjangan - tunjangan yang diberikan perusahaan kepada karyawan yaitu: Tunjangan Makan atau Menyiapkan Makan Bersama, Tunjangan Kesehatan atau Fasilitas Pengobatan dan Pemberian Uang Saku Secara Lump-Sum atau Reimbursemen [4].

\section{Microsoft Visual Studio}

Microsoft Visual Studio merupakan sebuahperangkat lunak lengkap (suite) yang dapat digunakan untuk melakukan pengembangan aplikasi, baik itu aplikasi bisnis, aplikasi personal, ataupun komponen aplikasinya, dalam bentuk aplikasi console, aplikasi Windows, ataupun aplikasi Web [5].

E. ERD (Entity Relation Diagram)

ERD adalah representasi grafis dari sistem informasi yang menunjukkan hubungan antara orang, objek, tempat, konsep atau kejadian di dalam sebuah system [6].

F. DFD

Data Flow Diagrams (DFD) menggambarkan komponen sistem, aliran data di antara komponen sistem tersebut, sumber data, tujuan, dan penyimpanan data [7].

Diagram arus data (data flow diagram) atau DFD adalah suatu gambaran grafis dari suatu sistem yang menggunakan sejumlah bentuk-bentuk simbol untuk menggambarkan bagaimana data mengalir melalui suatu proses yang saling berkaitan [8]. 


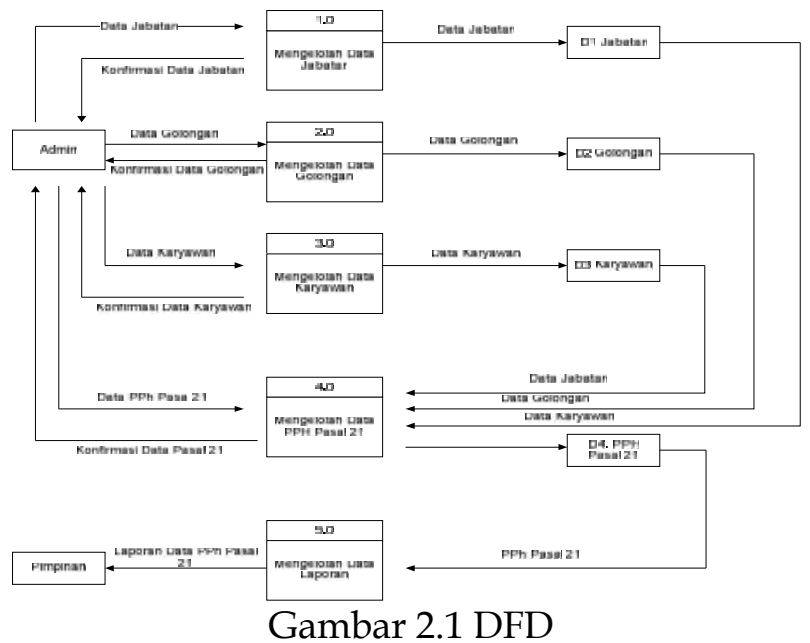

\section{Pembahasan}

A. Tahap Perancangan Basis Data

Pada tahap perancangan basis data, tampilan aplikasi perancangan persediaan barang berbasis Microsoft Visual Studio 2010 dan MySQL akan digambarkan dengan Entity Relation Diagram dibawah ini :

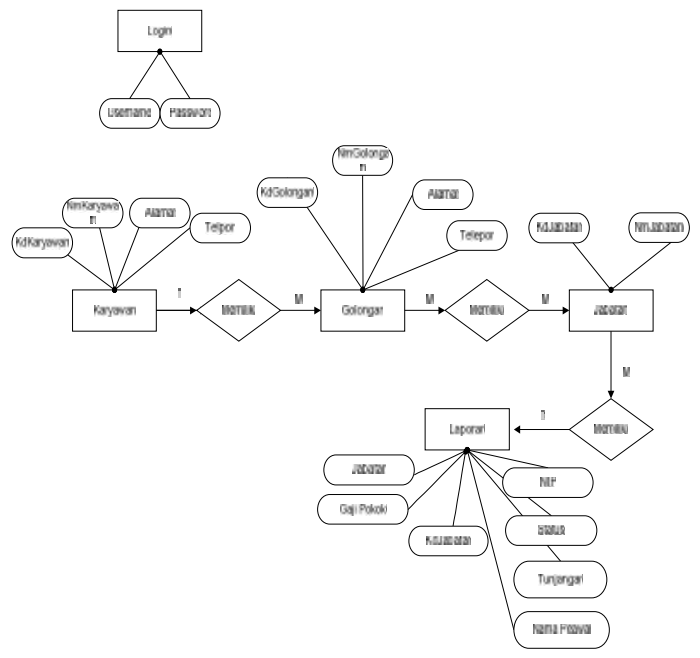

Gambar 2.2 Entity Relation Diagram

1. Tampilan Form Login 
Sistem Perhitungan PPH Pasal 21 atas Pembayaran Gaji Pegawai Kantor pada PT. Perkebunan Nusantara III Sei Mangkei

Tampilan menu login merupakan tampilan yang pertama kali dilihat oleh pengguna pada tahap ini user maupun admin melakukan proses login. Aplikasi ini hanya digunakan untuk satu user, yaitu karyawan yang khusus dibagian PPh Pasal 21.

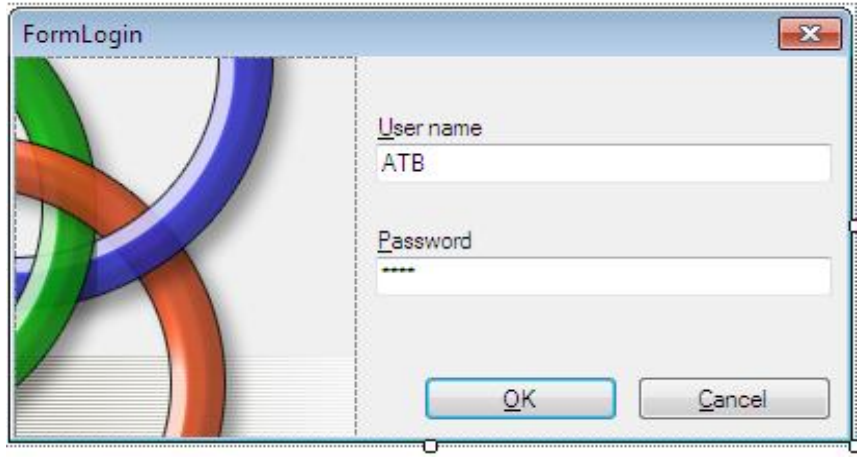

Gambar 2.3 Form Login

2. Tampilan Menu Utama

Setelah user berhasil login selanjutnya user ke form menu utama, pada menu utama baik user maupun admin dapat menginput data-data yang ada dengan memilih beberapa menu-menu seperti :

- Menu Master, isinya meliputi : karyawan, golongan, jabatan.

- Data Transaksi, isinya meliputi : potongan, PPN (\%).

- Laporan, isinya meliputi : kas masuk dan kas keluar.

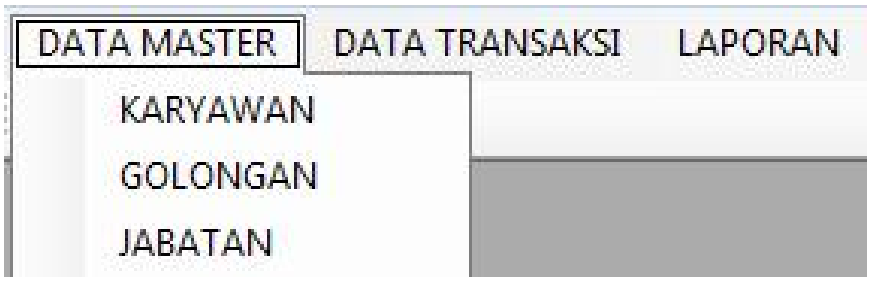



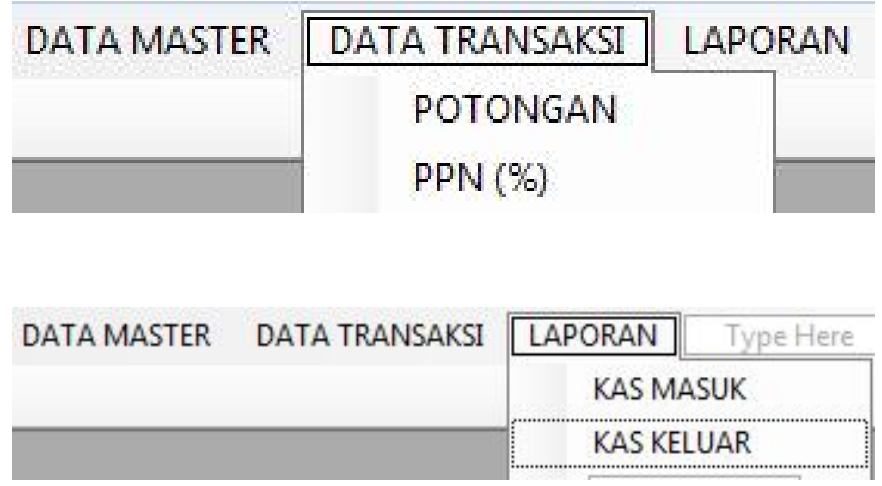

3. Karyawan

Pada Karyawan ini terdapat juga form Karyawan, berikut ini merupakan tampilan dari form Karyawan yang harus diinput.

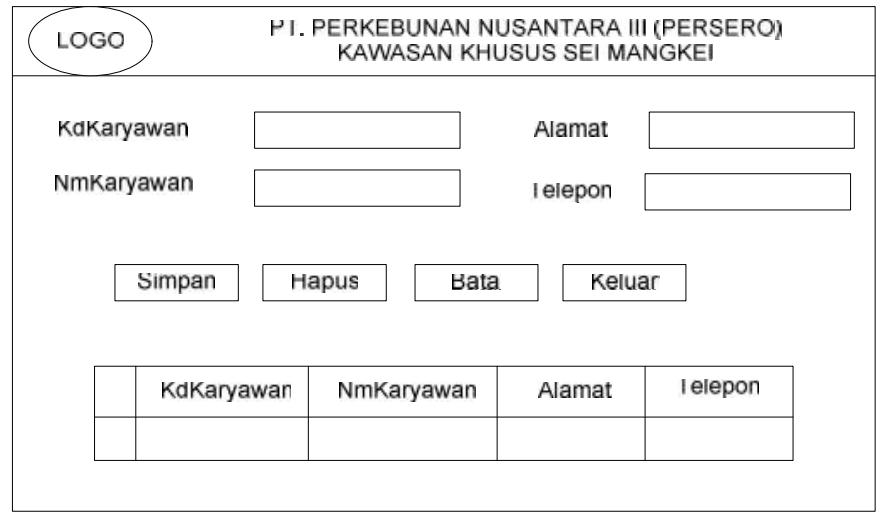

Gambar 2.4 Form Karyawan

4. Golongan

Pada golongan ini terdapat juga form Golongan, berikut ini merupakan tampilan dari form Golongan yang harus diinput. 
Sistem Perhitungan PPH Pasal 21 atas Pembayaran Gaji Pegawai Kantor pada PT. Perkebunan Nusantara III Sei Mangkei

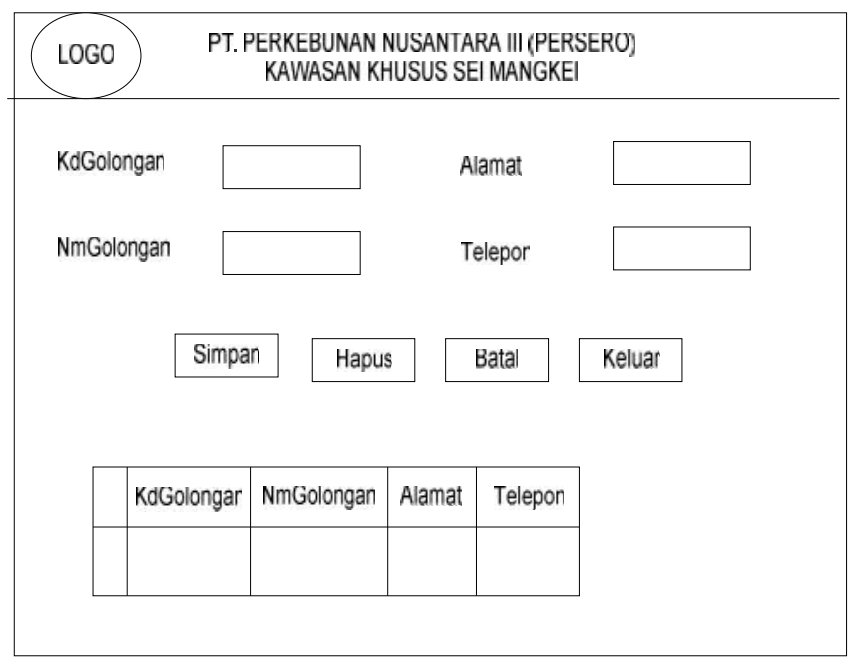

Gambar 2.5 Form Golongan

5. Jabatan

Pada Jabatan terdapat form jabatan, berikut ini merupakan tampilan dari form jabatan yang harus diinput.

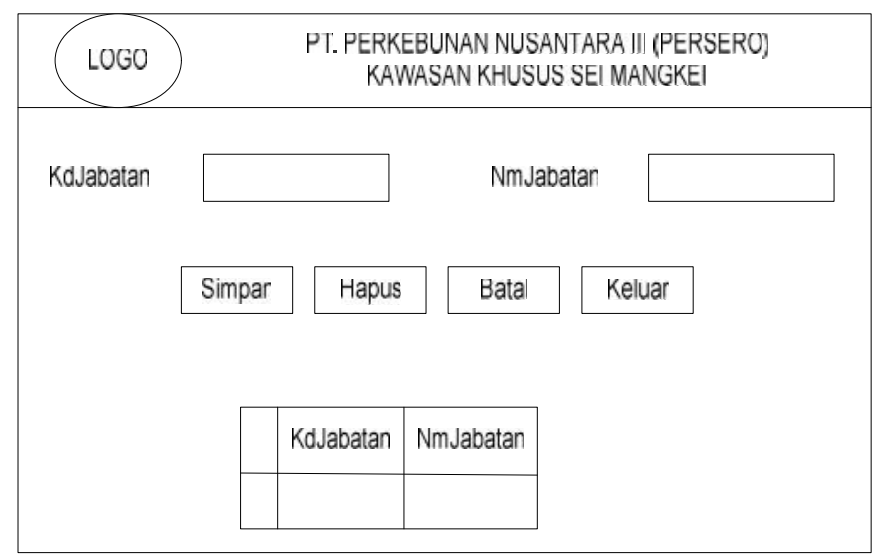

Gambar 2.6 Form Jabatan 


\section{Potongan}

Pada potongan ini terdapat juga Form potongan, berikut ini merupakan tampilan dari Form potongan yang harus diinput.

\begin{tabular}{|c|c|c|c|c|}
\hline (LO & ;0 PI. PEF & $\begin{array}{r}\text { BUNAN NUS } \\
\text { SEI }\end{array}$ & $\begin{array}{l}\text { ANTARA III KA } \\
\text { MANGKEI }\end{array}$ & VASAN KHUSUS \\
\hline Nama & aryawan & & & Simpan \\
\hline Gaji & & & & Hapus \\
\hline Potons & & & & Batal \\
\hline Total & & & & Keluar \\
\hline No & Nama Karyaw & Gaji & Potongan & Total \\
\hline 1 & Ayu & Rp. 5.000 .000 & Rp. 112.500 & Rp. 4.887 .500 \\
\hline 2 & Novi & Rp. 5.200 .000 & Rp. 267.000 & Rp. 4.933.000 \\
\hline 3 & Silvi & Rp. 4.500 .000 & Rp 110.000 & Rp. 4.389.000 \\
\hline
\end{tabular}

Gambar 2.7 Form Potongan

7. $\operatorname{PPN}(\%)$

Pada PPN ini terdapat juga Form PPN, berikut ini merupakan tampilan dari Form PPN(\%) yang harus diinput.

\begin{tabular}{|c|c|c|c|c|}
\hline LOGO & \multicolumn{4}{|c|}{$\begin{array}{l}\text { PI. PEKKEBUNAN NUSANIAKA III KAWNASAN KHUSUS SE } \\
\text { MANGKE }\end{array}$} \\
\hline NIF & & \multirow{2}{*}{\multicolumn{2}{|c|}{$\begin{array}{l}\text { Golongan } \\
\text { PPN }\end{array}$}} & \\
\hline NAMA & & & & \\
\hline \multicolumn{5}{|l|}{ Gaji } \\
\hline NIF & NAMA & GULUNGAN & GAJ| & PPN \\
\hline 1902010 & AYU & Manager & 1.000.000 & $1 \%$ \\
\hline 2618187 & NOVI & Staff & $4,500,000$ & $3 \%$ \\
\hline 650921 & SILV| & Karyawan & $5,000,000$ & $2 \%$ \\
\hline \multicolumn{2}{|c|}{ SIMPAN } & KELUAK & \multicolumn{2}{|l|}{ BAIAL } \\
\hline
\end{tabular}

Gambar 2.8 Form PPN

8. Laporan 
Sistem Perhitungan PPH Pasal 21 atas Pembayaran Gaji Pegawai Kantor pada PT. Perkebunan Nusantara III Sei Mangkei

Pada menu utama terdapat laporan,berikut ini merupakan tampilan dari laporan.

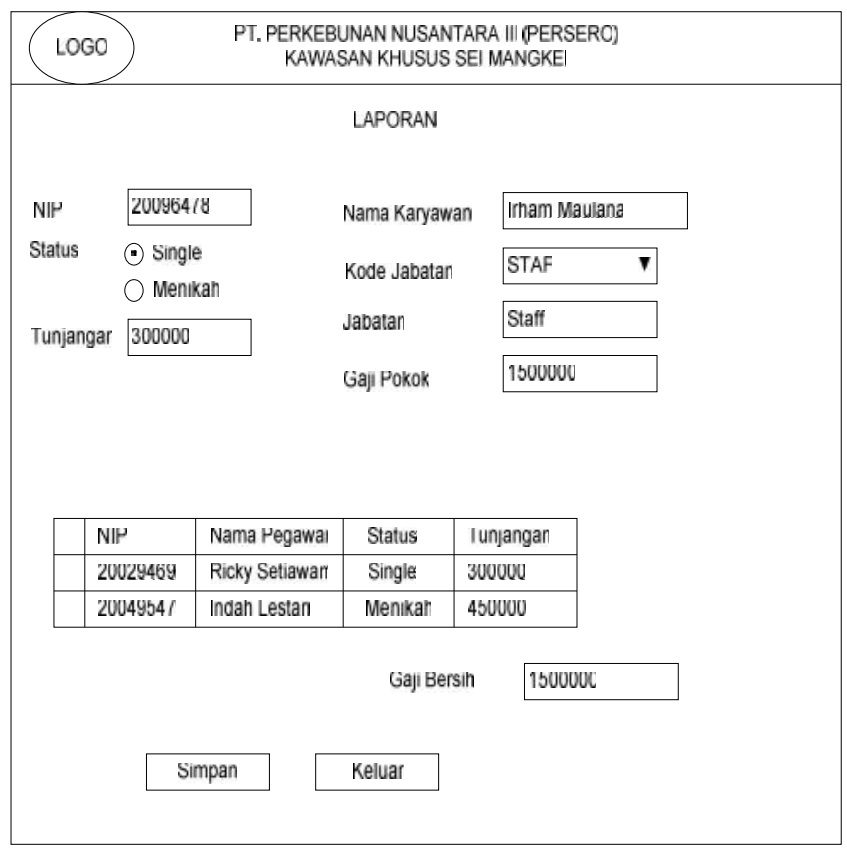

Gambar 2.9 Form Laporan

\section{Kesimpulan}

Dari hasil penelitian, dapat diambil kesimpulan sebagai berikut :

1. Proses perhitungan Pajak Penghasilan Pasal 21 atas gaji pegawai sudah sesuai dengan Undang-Undang yang berlaku.

2. Prosedur perhitungan pada Dinas Pendidikan Kecamatan Tuminting sudah dilakukan sesuai dengan Undang-Undang yang berlaku, tapi dalam proses perhitungan untuk mendapatkan penghasilan Neto belum sesuai dengan Undang-Undang Pasal 36 tahun 2008. Pada Dinas Pendidikan Kecamatan Tuminting untuk mendapatkan penghasilan neto, mengurangkan penghasilan bruto dengan potongan yang ada yaitu PFK dan Trumah. Sedangkan pada Undang-Undang No 
36 tahun 2008 untuk mendapatkan penghasilan neto adalah dengan mengurangkan penghasilan bruto dengan potongan, yaitu Biaya Jabatan dan Biaya Pensiun.

3. Proses pembayaran dan pelaporan PPh Pasal 21 yang dilakukan oleh Dinas Pendidikan Kecamatan Tuminting sudah dilakukan dengan baik dan benar sesuai dengan Undang-Undang No 36 tahun 2008. 


\section{Daftar Pustaka}

[1] S. Dotulong and S. S. P. H. Sabijono, "Penerapan Akuntansi untuk Pajak Penghasilan (PPH) Pasal 21 pada PT. Bank Mandiri (Persero) TBK Cabang Dotulolong Lasut," J. EMBA, vol. 2, no. 1, pp. 457-468, 2014.

[2] R. V. D. P. Vridag and Fakultas, "Analisis Perbandingan Penggunaan Metode NET Basis dan Metode Gross UP dalam Perhitungan Pajak Penghasilan Pasal 21 ( PPh Pasal 21 ) berupa Gaji dan Tunjangan Karyawan PT . Remenia Satori Tepas Manado," J. EMBA, vol. 3, no. 4, pp. 306-314, 2015.

[3] Jeane Susan, "Analisis Perhitungan Pajak Penghasilan Pasal 21 pada PT. Megasurya Nusalestari Manado," J. EMBA, vol. 1, no. 36, pp. 1599-1607, 2008.

[4] M. Dalughu and Fakultas, "Analisis Perhitungan dan Pemotongan PPh Pasal 21 pada Karyawan PT. BPR Primaesa Sejahtera Manado," Berk. Ilm. Efisiensi, vol. 15, no. 03, pp. 106-113, 2015.

[5] Herpendi, "Aplikasi Pengelolaan Nilai Akademik Mahasiswa dan DPNA ( Daftar Peserta dan Nilai Akhir)," vol. 2, no. June 2016, pp. 0-6, 2018.

[6] I. Lestari and H. Irawan, "Analisis Dan Desain Electronic Customer Relationship Management ( e- CRM ) Berbasis Web Guna Membina Serta Meningkatkan Loyaalitas Pentewa Studi Kasus : PT . Sari Indah Lestari( SIL ) - MALL CBD Ciledug," CKI SPOT, vol. 10, no. 2, pp. 47-53, 2017.

[7] D. T. A. Suhendro, "Perancangan dan Implementasi Realisasi Anggaran Pendapatan ( Studi Kasus: Pengadilan Negeri Klas IB Pematangsiantar )," 2017, pp. 30-36. 
[8] S. Trianovie, "Sistem Komputerisasi Penjualan Air Minum Mineral Isi Ulang PM Water R.O Sigambal dengan menggunakan Program Borland Delphi 7.0," J. INFOTEK, vol. 3, no. 1, pp. 39-44, 2018. 